\title{
Investigation of Entrepreneurship Trends and General Competency Levels of University Students Studying at Faculty of Sports Sciences
}

\author{
Ebru Olcay Karabulut ${ }^{1}$, Pinar Karacan Doğan ${ }^{2}$ \\ ${ }^{1}$ School of Physical Education and Sport, Ahi Evran University, Kırşehir, Turkey \\ ${ }^{2}$ Sports Sciences Faculty, Gazi University, Ankara, Turkey \\ Correspondence: Ebru Olcay Karabulut, School of Physical Education and Sport, Ahi Evran University, Kırşehir, \\ Turkey.
}

Received: February 6, 2018

doi:10.11114/jets.v6i4.3128
Accepted: March 15, $2018 \quad$ Online Published: March 23, 2018

URL: https://doi.org/10.11114/jets.v6i4.3128

\begin{abstract}
The aim of this study is to determine the general competency beliefs and entrepreneurial levels of undergraduate students studying at faculty of sports sciences by different demographic variables.

The sample group consists of total 1230 students, 541 women and 689 men, who have been educated in the sport sciences of five different universities and have been chosen by chance.

In this study, the entrepreneurship scale, composed of 36 items, developed by Yllmaz and Sümbül (2009) and the entrepreneurship scale, developed by Jerusalem and Schwarzer (1992) and General Self-Efficacy Scale (GSES), composed of 10 items, developed and adapted to Turkish by Çelikkaleli and Çapri (2008) were used as data collection tool.

For statistical analysis of the data obtained from the study, the mean and frequency distributions were obtained. In order to determine the relationship between gender variables and the scores of the participants, $t$-test was performed and ANOVA test was performed to determine the relationship between the grades (points/marks) of the participants. Kruskal Wallis test was used for non-parametric tests because the variables studied did not meet the normal distribution and homogeneity conditions. In order to determine the relationship between the two scales, Pearson correlation test was performed and presented as results and tables. For statistical significance .05 significance level was selected.

The results of the study show that the group has a high level of competency and entrepreneurship, that there is no meaningful relationship between gender variables and general competency and entrepreneurship levels, but that there is a meaningful relationship with the university variables they are studying. It has been determined that there is a positive correlation between the general level of competence of the students and the levels of entrepreneurship.
\end{abstract}

Keywords: entrepreneurship, physical education and sports teaching, general competency

\section{Introduction}

Although the concept of entrepreneurship is initially considered only as a concept of Economics, the intensive business life of the globalizing world is increasing the focus of all Sciences on entrepreneurship (Şeşen \& Basım, 2012). Entrepreneurship was initially defined as an attempt to start a business, to start a business and to take risks on this road, and then expanded as activities to reveal different views, to transform them into products and services and to market them (Zhao, 2005).

Entrepreneurship can also be defined as a process in which individuals explore, evaluate and utilize various processes and resources to take advantage of certain opportunities (Shane \& Venkataraman, 2000). Among the common characteristics of entrepreneurship are profit making (Hallak, Brown \& Lindsay, 2011) initiative, persuasion, problem solving (Gibb, 1987), motivation, having the necessary resources (Gibb \& Ritchie 1982), creative and innovative activities, good observation, high imagination, ambition, passion (Similor \& Sexton 1996), dynamism, stubbornness and creativity (Bridge, O’Neil \& Martin, 1998). The individual must be trust, believe and care themselves in order for these to be come true (Karacan Doğan, 2016). The entrepreneurial tendency refers to the willingness, determination and predisposition of the individual to do his job by making a new venture (Bozkurt, 2011; Chelariu, Brashear, Osmonbekov \& Zait, 2008; Wiklund \& Shepherd, 2008). When we say entrepreneurship tendency of students studying at the University, we see the potential entrepreneur concept (Chelariu et al., 2008). 
In our day, when entrepreneurship is very important, it is very important to identify entrepreneurial people and to educate them in the right way by educational institutions such as Universities. In order to plan and implement entrepreneurship education in a way that meets the needs of the economic sectors, universities have great responsibilities (Lekoko, Rankhumise \& Ras, 2012). The beneficiaries of entrepreneurship include athletes, fans, customers, governments, sponsors, communities and employees (Ekmekci \& İrmiş, 2017). In this context, the departments of the universities that provide sports sciences education are important institutions.

In the Sports Journal, the entrepreneur was defined as an organizer, and a risk-taker when engaging in a business venture (Ratten, 2010). In the field of Physical Education and sports, this situation comes up with a wide range of sports organizations, to be open to innovations in the field of sports, to use technology, to get income from sports drinks, to watch matches in special places, to market materials specially produced for athletes, to advertise, sponsorship, to brands of sports clubs and to goods with the developments in our country and the world. Students who will graduate from sports schools and faculties or who will be employed in new business areas or in the public sector are needed more. It is important to develop the entrepreneurship characteristics of the students, who are considered potential entrepreneurs, and to direct them to entrepreneurship activities.

One of the factors that affect the entrepreneurial characteristics of the students is their competence - competence beliefs. The person who feels competent about a subject will be more successful in entrepreneurship activities. From this point of view, belief in competence is important. Some mental abilities, such as desire to succeed, ambition, self-confidence, risk taking, and self-confident, are not available for money (Lamping \& Charles, 2000). Self-efficacy belief is one of the most important concepts of Social Learning Theory. It is defined by Bandura (1986) as "their beliefs about their confidence in the ability to bring together the behaviours necessary to perform the ability of individuals and to carry out these behaviours that they organize."

Although "competency belief" is widely used as a thought, some researchers, such as Zhang and Schwarzer (1995) and Choi (2004), focus on the concept of "general competency belief". Luszczynska et al. general competence defines the definition of the belief as "first of all, when a wide range of behaviours is considered, it is the belief that one believes in success and success, and the ability to demonstrate in this direction." (Quoted from: Çelikkaleli \& Çapri, 2008).

The belief of competence also affects the way people think and react emotionally. Individuals with a high level of self-efficacy can be more comfortable and productive when faced with work that has a high level of difficulty. People who have low competence believe that their work is even more difficult than it actually is. This type of thinking increases anxiety and stress, while narrowing the perspective that one needs to solve a problem in the best way. For this reason, self-efficacy belief strongly affects the level of success of individuals (Pajares, 2002).

Physical education is the whole of the regular and Methodological studies carried out with the aim of providing the physical, sensory and cognitive development of individuals, preparing daily life and work conditions, strengthening the feelings of national consciousness and citizenship. Sports men are the person who systematically transfers all of this to individuals. At this point, the sense of competence is key to physical education teachers, trainers and sports managers because the higher their belief in proficiency, the more successful and productive they will be in their profession (Yılmaz, Y1lmaz \& Türk, 2010). Sports, constructivist and producer skills, job, duties and professional responsibility to the individual, while protecting public resources and national energy sources and creating a good use of the consciousness (Kolayiş \& Taşkıran, 2001).

It is important to investigate the entrepreneurial levels of individuals involved in sport, one of the countries' economic power sources, and the beliefs of general competence. It is thought that people with high beliefs of competence have an influence on entrepreneurship levels. This research was carried out with the aim of filling the gap in the sample of the students who are studying sport sciences, as there are few studies investigating the triangle of sports, entrepreneurship and general competence beliefs.

\section{Method}

\subsection{Model of Research}

In the study, a survey method was used in which the most preferred (Thomas \& Nelson, 1996) groups were carried out in the descriptive research model, where the opinions of the people in the group about a case or a case were taken, their attitudes were taken, and the cases and events were tried to define as in their own conditions (Karasar, 2005).

\subsection{Research Group}

The sample group consists of a total of 1230 students, 541 women and 689 men, who have been educated in the sport sciences of five different universities and have been chosen by chance. The distribution of the students forming the research group according to various variables is as follows. 
Table 1. Frequency and percentage distributions of the research group in relation to demographic variables

\begin{tabular}{llll}
\hline Variables & & $\mathrm{f}$ & $\%$ \\
\hline \multirow{4}{*}{ University } & Ahi Evran University & 454 & 36,9 \\
& Niğde University & 331 & 26,9 \\
& Erciyes University & 182 & 14,8 \\
Gender & Mersin University & 153 & 12,4 \\
& Kirikkale University & 110 & 4,9 \\
& Female & 541 & 56 \\
Male & 18 & 689 & 7,7 \\
Age & 19 & 95 & 14,5 \\
& 20 & 178 & 17,5 \\
& 21 & 215 & 23,7 \\
Department & 22 & 291 & 15,4 \\
& 23 & 190 & 21,2 \\
& Sport Management & 261 & 28,9 \\
Grade & Physical Education and Sports Teaching & 356 & 40,4 \\
& Trainer Education & 497 & 30,7 \\
& 1 & 377 & 21,5 \\
\hline
\end{tabular}

\subsection{Data Collection Tools}

As a data collection tool, the personal data form prepared by the researcher in order to identify the sample group was used and then two different questionnaires related to the subject of the research were applied.

In this study, the General competency scale developed by Jerusalem and Schwarzer (1992) and the adaptation studies were made by Çelikkaleli and Çapri (2008) was used. The scale, consisting of 10 items and a Likert type measuring instrument, is scored as 1 "not correct" and 4 "completely correct". In the validity and reliability studies, it is stated that the scale consists of one dimension, as in the original scale, and the overall competence of the scale explains $45.78 \%$ of variance. Internal consistency coefficient in reliability studies of the scale. In the reliability studies of the scale, the internal consistency coefficient was .87 and the test-retest correlation coefficient was .92 . The height of the scores obtained from the measurement tool is considered to be high in belief in general competence. In this study, the internal consistency coefficient of the measurement tool was found to be 85 .

Secondly, Entrepreneurship scale, developed by Yllmaz and Sümbül (2009), consisting of 36 articles was used. Questionnaire sentences are organized in a 5-interval scale form, ranging from "very often" (5) to "never" (1). The lowest score from the scale is 36 and the highest score is 180 . Cronbach Alpha reliability analysis and factor analysis (validity analysis) were performed on the data obtained after the trial. Factor analysis performed by basic component analysis revealed that all materials were collected in one dimension. As a result of reliability analysis, Cronbach Alpha reliability coefficient was 0.90. The internal consistency coefficient of the measurement tool from the data collected in this study was found as 83.2.

\subsection{Data Analysis}

For statistical analysis of the data obtained from the study, the mean and frequency distributions were obtained. In order to determine the relationship between gender variables and the scores of the participants, $t$-test was performed and ANOVA test was performed to determine the relationship between the grades of the participants Kruskal Wallis test was used for non-parametric tests because the university variables studied did not meet the normal distribution and homogeneity conditions. In order to determine the relationship between the two scales, Pearson correlation test was performed and presented as results and tables. For statistical significance .05 significance level was selected.

\section{Results}

Table 2. Table of general competency and entrepreneurship scale averages of research group

\begin{tabular}{llcll}
\hline Scales & N & Min & Max & $\overline{\mathbf{X}}$ \\
\hline General Self-Efficacy Scale & 1230 & 10 & 40 & 32,68 \\
The Entrepreneurship Scale & 1230 & 36 & 180 & $\lfloor 42,77$ \\
\hline
\end{tabular}

In general, the research group has a high level of competence (Average: 32,68) and a high level of entrepreneurship (Average: 142,77). 
Table 3. T-test table based on gender variables of the research group's general competency and entrepreneurial level

\begin{tabular}{lccccccc}
\hline Scales & Gender & $\mathrm{N}$ & $\overline{\mathrm{X}}$ & $\mathrm{s}$ & $\mathrm{sd}$ & $\mathrm{t}$ & $\mathrm{p}$ \\
\hline General & Self-Efficacy & Female & 541 & 32,86 & 5,35 & \multirow{2}{*}{1228} & \multirow{2}{*}{$1,019,308$} \\
Scale & Male & 689 & 32,54 & 5,45 & & \\
The & Entrepreneurship Female & 541 & 143,98 & 21,66 & & \\
Scale & Male & 689 & 141,82 & 21,88 & & $1,731,084$
\end{tabular}

As the data in Table 3 shows, t-test analysis results show that there is no significant difference between the students' overall competency scale scores and entrepreneurship scale scores and gender variables $(\mathrm{p}>0.05)$.

Table 4. The results of ANOVA test according to the level of general competency of the research group and the level of entrepreneurship according to the university departments the research group studied

\begin{tabular}{|c|c|c|c|c|c|c|c|c|c|c|c|}
\hline Scales & Group & $\mathrm{N}$ & $\overline{\mathbf{X}}$ & sd & $\begin{array}{l}\text { Variance } \\
\text { Source }\end{array}$ & $\begin{array}{ll}\text { Sum } & \mathrm{o} \\
\text { Squares } & \end{array}$ & ${ }^{d f}$ & $\begin{array}{l}\text { Mean } \\
\text { Square }\end{array}$ & $\mathrm{F}$ & $\mathrm{p}$ & Different \\
\hline \multirow{3}{*}{$\begin{array}{l}\text { General } \\
\text { Self-Efficacy Scale }\end{array}$} & 1 & 356 & 33,30 & 5,70 & Inter Group & 206,88 & 2 & 103,44 & \multirow{3}{*}{3,55} & \multirow{3}{*}{, 029} & \multirow{3}{*}{-} \\
\hline & 2 & 497 & 32,54 & 5,38 & In-Group & 35705,23 & 1227 & 29,10 & & & \\
\hline & 3 & 377 & 32,29 & 5,09 & Total & 35912,11 & 1229 & & & & \\
\hline The & 1 & 356 & 147,49 & 22,79 & Inter Group & 11801,39 & 2 & 5900,69 & \multirow{3}{*}{$\begin{array}{l}12,6 \\
4\end{array}$} & \multirow{3}{*}{, $000^{*}$} & $1-2$ \\
\hline Entrepreneurship & 2 & 497 & 141,57 & 21,50 & In-Group & 572491,56 & 1227 & 466,57 & & & $1-3$ \\
\hline Scale & 3 & 377 & 139,88 & 20,53 & Total & 584292,96 & 1229 & & & & \\
\hline
\end{tabular}

Groups: 1. Departments of Sports Management, 2. Trainer Education, 3. Physical Education and Sports Teaching $(\mathrm{p}<, 05)$

As shown in Table 4, the general level of competence of the students does not differ significantly from that of the university departments the research group studied $(\mathrm{p}<.005)$

In Table 4, the entrepreneurial scale shows that the scores of the students differ significantly from those of the Department variable they read $[\mathrm{t}(1230)=12,64 ; \mathrm{p}<, 05]$. It was found that the scores of the students of sports Management Department $(\bar{x}=147.49)$, the scores of the students who received trainer education $(\bar{x}=141.57)$ and the scores of the students who received Physical Education and sports Education $(\bar{x}=139.88)$ were higher.

Table 5. The ANOVA results based on the class variable of the Research Group's general competency and entrepreneurial level

\begin{tabular}{|c|c|c|c|c|c|c|c|c|c|c|c|}
\hline Scales & Group & $\mathrm{N}$ & $\overline{\mathbf{X}}$ & sd & $\begin{array}{l}\text { Variance } \\
\text { Source }\end{array}$ & $\begin{array}{l}\text { Sum } \\
\text { Squares }\end{array}$ & of $\mathrm{df}$ & $\begin{array}{l}\text { Mean } \\
\text { Square }\end{array}$ & $\mathrm{F}$ & $\mathrm{p}$ & Different \\
\hline \multirow{4}{*}{$\begin{array}{l}\text { General } \\
\text { Self-Efficacy } \\
\text { Scale }\end{array}$} & 1 & 265 & 2,22 & 5,52 & Inter Group & 613,15 & 3 & 204,38 & \multirow{4}{*}{7,09} & \multirow{4}{*}{, $000 *$} & \multirow{4}{*}{$\begin{array}{l}3-1 \\
3-2 \\
3-4\end{array}$} \\
\hline & 2 & 317 & l,76 & 5,66 & In-Group & 35298,96 & 1226 & 28,79 & & & \\
\hline & 3 & 288 & 3,51 & 5,20 & Total & 3501211 & 1220 & & & & \\
\hline & 4 & 360 & 3,18 & 5,09 & Iotal & 35912,11 & 1229 & & & & \\
\hline \multirow{3}{*}{$\begin{array}{l}\text { The } \\
\text { Entrepreneurship } \\
\text { Scale }\end{array}$} & 1 & 265 & $+2,38$ & 20,76 & Inter Group & 9757,11 & 3 & 3252,37 & \multirow{3}{*}{6,94} & \multirow{3}{*}{, $000 *$} & \multirow{3}{*}{$\begin{array}{l}3-1 \\
3-2 \\
3-4\end{array}$} \\
\hline & 2 & 317 & 38,89 & 21,29 & In-Group & 574535,84 & 1226 & 468,62 & & & \\
\hline & 3 & $\begin{array}{l}288 \\
360\end{array}$ & $\begin{array}{r}16,89 \\
1218\end{array}$ & 21,05 & Total & 584292,96 & 1229 & & & & \\
\hline
\end{tabular}

As shown in Table 5, the general level of competence of the students differs significantly from the class variable they read ( $\mathrm{p}<.005)$. The marks of 3rd Class students $(\bar{x}=33.51)$, was higher than the students of 1st Class $(\bar{x}=32,22)$, 2nd class $(\bar{x}=31.76)$ and 4 th class $(\bar{x}=33,18)$.

In Table 5, It is observed that the students ' entrepreneurship scale scores differ significantly from the class variable they read. $\left[\mathrm{t}_{(1230)}=6,94 ; \mathrm{p}<, 05\right]$. The Marks of 3rd class students $(\bar{x}=146,89)$, was higher than those of 1st Class $(\bar{x}=142.38)$, 2nd class $(\bar{x}=138,89)$ and 4th class $(\bar{x}=143,18)$. 
Table 6. Kruskal-Wallis test results based on the university variable of the research group's general competency and entrepreneurial level

\begin{tabular}{|c|c|c|c|c|c|c|c|}
\hline Scales & Variables & $\mathrm{N}$ & Mean Rank & $\mathrm{sd}$ & $\mathrm{X}^{2}$ & p & \multirow[t]{2}{*}{ Differen } \\
\hline \multirow{5}{*}{ General Self-Efficacy Scale } & Ahi Evran U. (1) & .54 & 563,80 & \multirow{5}{*}{4} & \multirow{5}{*}{112,78} & \multirow{5}{*}{, $000 *$} & \\
\hline & Niğde U. (2) & 31 & 608,08 & & & & $4-1$ \\
\hline & Erciyes U. (3) & 82 & 602,86 & & & & 4-2 \\
\hline & Mersin U. (4) & 53 & 887,12 & & & & $\begin{array}{l}4-3 \\
4-5\end{array}$ \\
\hline & Kırıkkale U. (5) & 10 & 494,28 & & & & \\
\hline \multirow{5}{*}{ Entrepreneurship } & Ahi Evran U. (1) & .54 & 545,84 & \multirow{5}{*}{4} & \multirow{5}{*}{150,10} & \multirow{5}{*}{, $000 *$} & \\
\hline & Niğde U. (2) & 31 & 595,78 & & & & 4-1 \\
\hline & Erciyes U. (3) & 82 & 592,08 & & & & $4-2$ \\
\hline & Mersin U. (4) & 53 & 939,30 & & & & $\begin{array}{l}4-3 \\
4-5\end{array}$ \\
\hline & Kırıkkale U. (5) & 10 & 550,71 & & & & \\
\hline
\end{tabular}

As shown in Table 6, the general level of competence of the students differs significantly in terms of the University variable they read $(\mathrm{p}<.005)$. The marks of students at Mersin University $(\bar{x}=887,12)$ was found to be higher than the students studying at Ahi Evran University. $(\bar{x}=563,80)$, Niğde University $(\bar{x}=608,08)$, Erciyes University $(\bar{x}=$ $602,86)$ and Kırıkkale University ( $\bar{x}=494,28)$.

In Table 6, It is also observed that the students ' entrepreneurship scale scores differ significantly from the University variable they read. $\left[\mathrm{t}_{(1230)}=150,10 ; \mathrm{p}<, 05\right]$. The marks of students at Mersin University $(\bar{x}=939,30)$, was found to be higher than the students studying at Ahi Evran University $(\bar{x}=545,84)$, Niğde University $(\bar{x}=595,78)$, Erciyes University $(\bar{x}=592,08)$ and Kırıkkale University $(\bar{x}=550,71)$.

Table 7. Pearson's Moments Multiplication Correlation Coefficient Results, which show the relationship between the overall competency confidence scale and the entrepreneurial scale scores of the research group

\begin{tabular}{lllll}
\hline Scales & & & General Self-Efficacy Scale & The Entrepreneurship Scale \\
\hline \multirow{2}{*}{ General } & Self-Efficacy & $\mathrm{r}$ & 1 &, $578^{* *}$ \\
Scale & $\mathrm{p}$ & &, 000 \\
& & $\mathrm{~N}$ & 1230 & 1230 \\
The & Entrepreneurship & $\mathrm{r}$ &, $578^{* *}$ & 1 \\
$\mathrm{~N}$ & $\mathrm{p}$ &, 000 & \\
Scale & $\mathrm{N}$ & 1230 & 1230 \\
\hline
\end{tabular}

The results of the correlation in Table 7 show that there is a positive and meaningful relationship between the general level of competence of the students and the levels of entrepreneurship.

\section{Discussion}

In this study, it was aimed to determine the general competency beliefs and entrepreneurial levels of university students studying Faculty of Sports Sciences with different demographic variables.

The social and professional competencies of the students studying education in universities are important concepts for the education of future generations. It is also expected that the education for 4 years will contribute positively to the students, and that their confidence, competence and entrepreneurial characteristics will develop. It is also important to determine the competency levels and entrepreneurial characteristics of the university students studying in the faculty of sports sciences and to determine the factors that affect these characteristics.

When the research findings were examined in general, it was found that the study group has a high level of competence (Average: 32,68) and a high level of entrepreneurship (Average: 142,77) (Table 2). The relevant result can be interpreted as that the students who study sports sciences rely on their own competencies, are determined to accomplish a task, fulfil their responsibilities, and have ambitious, are persuasive, high-risk taking and have highly entrepreneurial skills. In addition to the effect of the education they received at the University on these results, it can also be thought that sports have positive contributions to the physical, social and emotional development of individuals. Because sport is an activity that improves all aspects of the individual.

This result, obtained from the study, is seen to be parallel to the literature compared to the different studies. At the study of Uluyol (2013) on entrepreneurial trends of Gölbaşı Vocational High School, at the study of Korkmaz (2012) on Bülent Ecevit University, Faculty of Economics and Administrative Sciences, Department of Business Administration, in order to determine students' entrepreneurship trends, at the study of Thandi and Sharma (2003) on measuring MBA students' entrepreneurship trends, at the study of Sarıtaş and Duran (2017) on determining the personal characteristics of the students and the factors affecting the success of entrepreneurship of the students at Mehmet Akif Ersoy University, it was determined that students have a high level entrepreneurship tendency. In the study of Tabancalı and Çelik (2013) 
on the relationship between the academic self-efficacy of teacher candidates and teacher self-efficacy, Çelikkaleli and Akbay (2013), in the study of university students' academic postponement behaviour, general competency belief and responsibilities of the students, determined that the students have general belief of competence. Literature studies show that university education contributes positively to the overall level of competence and entrepreneurship of individuals.

The other finding in the research is that the gender variable of the research group does not affect both the beliefs of competence and the levels of entrepreneurship (Table 3). The students who receive Sports Science Education are given special skills tests and have similar skills. In this respect, it is also natural that there is no difference between genders. The studies of Cengiz, Serdar and Donuk (2016), Bilge and Bal (2012), Özman (2013), Yilmaz (2014 ) on entrepreneurship, the studies of Pekel (2016), Abbasoğlu (2011), Varol (2007), Sandıklı and Öncü (2013) on competency support the findings of the studies However, Türkmen and Işbilir (2014), Şeşen and Basım (2012) and Wang and Wong (2004) found that men's entrepreneurship levels and competency beliefs were high in their studies, while Demir, Eliöz, Çebi and Sezen (2015), Yüzükak (2010) determined that women's entrepreneurship levels and competency beliefs were high. These studies don't support research findings. The differences in the results may be due to the variability of the scales used or the differences of the research groups.

Another result of the study is that the departmental variable of the research group does not affect the belief in competence but affects the level of entrepreneurship (Table 4). The entrepreneurial scores of the students who study sports management are higher than the students of the Department of trainer education and physical education and sports teaching. The result can be considered to be related to the quality of the courses in the Sport Management Department and to the differences between the students. Cengiz et al. (2016) in their study, determined that there was a difference between the variable of the Department and that the students of the Department of recreation had high level of entrepreneurship compared to other departments. Since there is no study on general competency belief and physical education departments, this study may be of importance.

Another finding is that the class variable affects the beliefs of general competence and entrepreneurial levels (Table 5). For 3rd class students, on both scales, the grade average of the students is high. It can be interpreted that the students who have come to the class have assimilated the education they have taken and understood the values that they have added to themselves, discovered their own potentials, felt self-competent in general, and are more excited and more entrepreneurial about the future. Since1st and 2nd classes have started teaching new education and have less experience on general courses, due to their graduation and future concerns, they can be considered to have a low score because they aim themselves emotionally at different areas. The studies of Türkmen and Işbilir (2014), Alemdag, Öncü and Yılmaz (2014) support these findings. Bozkurt (2013) has determined that students at $1^{\text {st }}$ class have higher self-efficacy and Varol (2007) has determined that students at 2nd. class have teaching higher self-efficacy.

Another finding in the research is that there is a difference in general competency beliefs and entrepreneurship levels according to the University variable studied by the research group (Table 6). Mersin university students received the highest scores on both scales. This emerging situation can be thought to be due to the fact that Mersin is a place with a population that is larger than the other cities, and because the city is near the sea, and port businesses, applications, free trade zone and business areas are wider, it is a different region, and also due to demographic variability of the students.

The correlation results in the research findings show that there is a positive and meaningful relationship between the general level of competence of the students and the levels of entrepreneurship. This can be interpreted as increasing levels of entrepreneurship as students increase their overall competence levels. In addition to this, researchers such as Drnovsek, Wincent and Cardon (2009), Boyd and Vozikis (1994), Shapero (1982) describe this situation as "entrepreneurial competence" and think that when a person encounters an opportunity, they feel of success and desire to achieve it and affect their entrepreneurial skills. Based on this information, it can be said that the group possesses high entrepreneurial and competence (Table 1), and they have high entrepreneurial competence.

\section{Conclusion and Recommendations}

As a result, it was found that the research group had a high level of competency and entrepreneurship, that there was no significant relationship between gender variables and the General competency belief and Entrepreneurship tendency, but that they had a significant relationship with the University variables they studied. It has been determined that there is a positive correlation between the general level of competence of the students and the levels of entrepreneurship.

Although there are studies on entrepreneurship level and competence, self-efficacy, professional competence, the studies at the literature about general competency belief and entrepreneurial tendency are low. The following suggestions can be obtained as a result of the findings and the literature studied.

-More emphasis should be placed on entrepreneurship education in universities.

-Universities should carry out activities that improve students' general level of competence. 


\section{References}

Abbasoğlu, E. (2011). Beden ĕgitimi öğretmeni adaylarının öğretmenlik mesleğine ilişkin tutum ve benlik sayglarının incelenmesi. Master Thesis. Karadeniz Technical University, Institute of Educational Sciences Trabzon.

Alemdă̆, C., Öncü, E., \& Yılmaz, A. K. (2014). Preservice physical education teachers' academic motivation and academic self-efficacy. Hacettepe Journal of Sport Sciences, 25(1), 23-35.

Bandura, A. (1986). Social foundations of thought and actions, Englewood Cliffs, N.J.: Prentice-Hall.

Bilge, H., \& Bal, V. (2012). Entrepreneurship aptitude: An empirical study on undergraduate and vocational high school students in Celal Bayar University. Journal of Süleyman Demirel University Institute of Social Sciences, 2(16), 131-148. Retrieved from https://dergipark.gov.tr/download/article-file/215334

Boyd, N. G., \& Vozigkis, G. S. (1994). The influence of self-efficacy on the development of entrepreneurial intentions and actions. Entrepreneurship Theory and Practice, 18, 63-68. https://doi.org/10.1177/104225879401800404

Bozkurt, Ö. Ç. (2011). Dünyada ve Türkiye’de girişimcilik ĕgitimi: başarıll girişimciler ve ögretim üyelerinden öneriler. Ankara: Detay.

Bozkurt, T. M. (2013). Beden eğitimi öğretmeni adaylarının öğretmenlik öz yeterliliklerinin incelenmesi, Gazi University Institute of Educational Sciences, Master Thesis, Ankara.

Bridge, S., O’Neil K., \& Martin, F. (1998). Understanding enterprise, entrepreneurship and small business, London: Macmillan Business.

Cengiz, R., Serdar, E., \& Donuk, B. (2016). Analyzing the level of mindfulness and entrepreneurship of the university students, International Journal of Social Sciences and Education Research, 2(4), Retrieved from https://dergipark.gov.tr/ijsser.

Chelariu, C., Brashear, G. T., Osmonbekov, T., \& Zait, A. (2008). Entrepreneurial propensity in a transition economy: Exploring micro-level and meso-level cultural antecedents, Journal of Business \& Industrial Marketing, 23(6), 405-415. https://doi.org/10.1108/08858620810894454

Choi, N. (2004). Sex role group differences in specific, academic, and general selfefficacy. The Journal of Psychology, 138(2), 149-159. https://doi.org/10.3200/JRLP.138.2.149-159

Çelikkaleli, Ö., \& Çapri, B. (2008). The validity and reliability study of the Turkish version of the General self-efficacy scale, Journal of Çukurova University İnstitute of Social Sciences, 7(3), 93-104. Retrieved from https://dergipark.ulakbim.gov.tr/cusosbil/article/view/5000001304/5000001995

Demir, A. Z., Eliöz, M., Çebi, M., \& Sezen, S. (2015). Entrepreneurship and Entrepreneurial University: A Study on the Students of Faculty of Sports., OMU Journal of Faculties Education. 34(1), 198-212. Retrieved from https://dergipark.ulakbim.gov.tr/omuefd

Drnovsek, M., Wincent, J., \& Cardon, M. S. (2009). Entrepreneurial self efficacy and business start-up: Developing a multidimensional definition. International Journal of Entreprenurial Behavior and Research, 16(4), 329-348. https://doi.org/10.1108/13552551011054516

Ekmekçi, Y. A., \& İrmiş, A. Entrepreneurship and sport. Retrieved from https://www.avekon.org/papers/754.pdf

Gibb, A. A. (1987). Enterprise culture- Its meaning and 1mplications for education and training, Journal of European Industrial Traing, 11 .

Gibb, A. A., \& Ritchie, J. (1982). Understanding the process of starting a small business, European Small Business Journal, 1 (1). Retrieved from https://doi/abs/10.1177/026624268200100102

Hallak, R., Brown, G., \& Lindsay, J. N. (2011). The place identity - performance relationship among tourism entrepreneurs: A structural equation modelling analysis, Tourism Management, 33(1), 143-154. Retrieved from https://doi/abs/10.1108/13552550510580825

Jerusalem, M., \& Schwarzer, R. (1992). Self-efficacy as a resource factor in stress appraisal processes. In R. Schwarder (Ed.), Self-efficacy: Thought Control of Action (pp. 195-213). Washington, DC: Hemisphere.

Karacan, D. P. (2016). Etkili iletişim. In A. A. Yetim \& R. Cengiz (Eds.), Sporda etkili iletişim (s. 91-122). Ankara: Spor.

Karasar, N. (2005). Scientific research method. 14. Issue. Ankara: Nobel.

Kolayiş, H., \& Taşkıran, Y. (2001). Beden eğitimi öğretmeninin yetenek seçimindeki rolü. Uludă̆ Üniversitesi II. Ulusal Beden Ĕgitimi ve Spor Öğretmenliği Sempozyum Kitabı, pp.164, AK MAT Matbaacılık, Bursa. 
Korkmaz, O. (2012). A research on determining the entrepreneurialism inclination of university students: Bülent Ecevit University example. Afyon Kocatepe University Journal of Economics and Administrative Sciences, 14(2), 209-226. Retrived from http://dergipark.gov.tr/download/article-file/18888

Lambing, P., \& Charles, R. (2000). Entrepreneurship, Second Edition, New York: Prentice Hall. (9-17).

Lekoko, M., Rankhumise, E. M., \& Ras, P. (2012). The effectiveness of entrepreneurship education: what matters most? African Journal of Business Management, 6(51), 12023-12033. https://doi.org/10.5897/AJBMx12.001

Özman, C. (2013). Spor yöneticiliği bölümünde öğrenim gören üniversite öğrencilerinin girişimcilik düzeylerinin belirlenmesi. Master Thesis. Marmara University, Institute of Healt Sciences, İstanbul.

Pajares F. (2002). Overview of social cognitive theory and of self efficacy. Retrieved from https://www.emory.edu/EDUCATION/MFP/eff.html

Pekel, A. (2016). Spor yöneticiliği bölümünde öğretim gören ögrencilerin akademik öz yeterlilikleri ve üniversite yaşam kalitesi arasindaki ilişkinin incelenmesi, Erciyes University, Department of Physical Education ans Sport, Kayseri.

Ratten, V. (2010). Developing a theory of sport-based entrepreneurship, Journal of Management and Organization, 16, 557-565. https://doi.org/10.1017/S1833367200001930

Sandıkçı, M., \& Öncü, E. (2013). Determination and comparison of physical education and the other pre-service teachers' self-efficacy beliefs and attitudes toward teaching profession, Pamukkale Journal of Sport Sciences, 4(1), 135-151. Retrived from http://dergipark.gov.tr/download/article-file/191780

Sarıtaş, A., \& Duran, G. (2017). A Research to determine the entrepreneurial tendency of university students. Journal of Social Sciences of Muş Alparslan University, 5(1), 147-165.

Shane, S., \& Venkataraman, S. (2000). The promise of entrepreneurship as a field of research, Academy of Management Review. 25(1), 217-226. https://doi.org/10.5465/AMR.2000.2791611

Shapero, A. (1982). Social dimensions of entrepreneurship. In C. Kent, D. Sexton, \& K. Vesper (Eds.), The encyclopedia of entrepreneurship. pp. 72-90. Englewood Cliffs, NY: Prentice Hall.

Smilor, W. R., \& Sexton, D. I. (1996). Leadership and entrepreneurship: Personal and organizational development in entrepreneurial ventures, Lon: Qurum Books,

Şeşen, H., \& Basım, H. N. (2012) The Impact of demographic factors and personality on the entrepreneurial intention: A Study on students in sport sciences departments. Ege Academic Review, 12, 21-28. Retrieved from https://s3.amazonaws.com/academia.edu.documents/38291141/

Tabancal1, E., \& Çelik, K. (2013). The relationship between academic self-efficacy and self-efficacy levels of teacher candidates. International Journal of Human Sciences, 10(1), 1167-1184. Retrived from https://www.j-humansciences.com/ojs/index.php/IJHS/article/view/2604

Thandi, H., \& Sharma, R. (2003). MBA students and entrepreneurship: An Australian study of entrepreneurial intentions and actualization, Jirsea, 2(1), 12-24.

Thomas, J. R., \& Nelson, J. K. (1996). Research methods in physical activity (3rd ed.). Champaing, IL: Human Kinetics.

Türkmen, M., \& İşbilir, U. (2014). Entrepreneurship effect of tendency of socio-demographic characteristics of university students, CBÜ Beden Eğitimi Spor Bilimleri Dergisi / CBU Journal of Physical Education Sports Sciences. 9(2) 18-28.

Uluyol, O. (2013). Research of students' entrepreneurship tendencies: Sample of Gölbaşı vocational college, Adiyaman University Journals of Social Science, 6(15), 350-372. Retrived from http://dergipark.ulakbim.gov.tr/adyusbd/article/view/5000041588/5000039116

Varol, B. (2007). Beden ĕgitimi ve spor bölümü ögrencilerinin öğretmenlik mesleğine ilişkin öz yeterlilikleri (Niğde Üniversitesi Örneği). Master Thesis. Niğde University, Institute of Social Sciences, Niğde.

Wang, K. C., \& Wong, P. K. (2004). Entrepreneurial interest of university students in singapore", Technovation, 24, 163-172. https://doi.org/10.1016/S0166-4972(02)00016-0

Wiklund, J., \& Shepherd, D. (2005). Entrepreneurial orientation and small business performance: a configurational approach, Journal of Business Venturing, 20, 71-91. https://doi.org/10.1016/j.jbusvent.2004.01.001

Yilmaz G., Yılmaz, B., \& Türk, N. (2010). Over-graduate thesis physical education and sports teacher's self efficacy of their jobs (Nevşehir City Model) Selçuk University Journal of Physical Education and Sport Science, 12(2), 85-90. 
Retrived from https://www.researchgate.net/profile/Guerkan_Yilmaz/publication

Yılmaz, A. S. (2014). Entrepreneurship education as a social changing agent. Zeitschrift für die Welt der Türken Journal of World of Turks, 6(1), 297-310.

Yılmaz, E., \& Sümbül, A. M. (2009). Üniversite öğrencilerine yönelik girişimcilik ölçeğinin geliştirilmesi, Selçuk Üniversitesi, Sosyal Bilimler Enstitüsü Dergisi, 21, 195-203. Retrieved from https://dergisosyalbil.selcuk.edu.tr/susbed/article/view/318/300

Yüzüak, E. (2010). The factors effect on entrepreneurial intentions of female students in the universities: Canakkale Onsekiz Mart University Biga I.I.F.B. sample, Master Thesis. Onsekız Mart University, Institute of Social Sciences, Çanakkale.

Zhang, J. X., \& Schwarzer, R. (1995). Measuring optimistic self-beliefs: a Chinese adaptation of the General Self-Efficacy Scale. Psychologia, 38(3), 174-181. Retrieved from https://psycnet.apa.org/record/1996-35921-001

Zhao, F. (2005). Exploring the synergy between entrepreneurship and innovation. International Journal of Entrepreneurial Behavior \& Research, 11(1), 25-41. https://doi.org/10.1108/13552550510580825

\section{Copyrights}

Copyright for this article is retained by the author(s), with first publication rights granted to the journal.

This is an open-access article distributed under the terms and conditions of the Creative Commons Attribution license which permits unrestricted use, distribution, and reproduction in any medium, provided the original work is properly cited. 